\title{
Forecasting mussel settlement using historical data and boosted regression trees
}

\author{
Javier Atalah*, Barrie M. Forrest \\ Cawthron Institute, Private Bag 2, Nelson 7010, New Zealand
}

\begin{abstract}
Many aquaculture sectors internationally, most notably for the cultivation of bivalves, rely almost completely on wild-caught juveniles ('spat') to stock farms, with poor 'catches' representing one the biggest constraints on global production. An example of this practice is green-lipped mussel Perna canaliculus aquaculture in New Zealand, where the industry in the main growing region has been monitoring $P$. canaliculus settlement for almost 40 yr. This practice involves deploying settlement arrays across the region to guide the places and times to place spatcatching rope. Using a subset of these data spanning 25 yr (1993-2018), we identified regional spatio-temporal patterns of $P$. canaliculus spat settlement. Boosted regression tree (BRT) models were used to forecast settlement at 2 different sub-regions with consistent high catch yields. BRT models confirmed a strong seasonal influence on settlement, with highest predicted settlement levels coinciding with the main P. canaliculus spawning period (late summer to autumn). Positive relationships were detected between settlement and the occurrence of positive temperature anomalies, easterly winds, periods of large tidal range and Southern Ocean Oscillation Index values associated with La Niña episodes. The models were able to forecast $P$. canaliculus settlement with excellent prediction accuracy based on time of year and environmental conditions 1 mo prior to collection. This study highlights the benefit of undertaking long-term monitoring of spat settlement and the related environmental factors that affect this ecological process. In combination with advance modelling techniques that enable forecasting of settlement densities, such knowledge can help to overcome challenges in spat supply and enable production upscaling.
\end{abstract}

KEY WORDS: Settlement · Green-lipped mussel $\cdot$ Perna canaliculus $\cdot$ Spat $\cdot$ Boosted regression trees

\section{INTRODUCTION}

Aquaculture production of many marine organisms relies on wild-caught juveniles to stock sea-based grow-out systems, including shrimps, various fish species and most notably bivalves, such as oysters and mussels (Hair et al. 2002). In the case of mussel aquaculture, global production totalled 2.16 million tonnes valued at US $\$ 4.27$ billion in 2017 , with the main producing countries being China, Spain, Chile, New Zealand and South Africa (FAO statistics, www.fao.org). Global mussel aquaculture involves 9 different species within 2 genera (Mytilus and Perna), in addition to a relatively smaller production of 2 other mytilids in

*Corresponding author: javier.atalah@cawthron.org.nz
South America (Aulacomya atra and Choromytilus chorus). For aquaculture of all of these species, juvenile seed-stock (referred to as 'spat') are typically collected either from natural substrata (Alfaro et al. 2010, Kamermans \& Capelle 2018) or from artificial settlement surfaces deployed in the water column (Pérez Camacho et al. 1995, Lauzon-Guay et al. 2005, Díaz et al. 2014). Despite some advantages of this practice, mainly relating to cost-efficiency, constraints on wild spat supply, or uncertainty in terms of the timing and magnitude of spat availability, can lead to insufficient juveniles to meet industry demand (Jeffs et al. 1999, Kamermans et al. 2013). Although recent technological advances in hatchery-

() The authors 2019. Open Access under Creative Commons by Attribution Licence. Use, distribution and reproduction are unrestricted. Authors and original publication must be credited. 
based production of mussel spat may go some way to mitigate this risk (Kamermans et al. 2013, Symonds et al. 2018), it is expected that the industry will continue to be mostly reliant on wild spat for the foreseeable future. In this context, the shortage and the spatio-temporal variability of wild-caught spat are currently among the biggest limitations on mussel industry growth internationally.

Like many ecological processes, mussel spat settlement is complex and highly variable, and dependent on a multitude of abiotic and biotic factors that lead to high spatio-temporal variability in settlement (Fuentes \& Molares 1994, Bownes \& McQuaid 2009, Atalah et al. 2017), as well as the subsequent secondary migration of settled juveniles (South et al. 2017). Settlement variability has been related to factors that affect the timing, magnitude and location of larval supply, such as the timing of adult spawning events, seston quality and availability to larvae (Toupoint et al. 2012), predation on larvae in the plankton (Cáceres-Martínez \& Figueras 1998, Pineda et al. 2010), the vertical depth-distribution of larvae in the water column (Fuentes \& Molares 1994) and the presence of conspecifics as a cue for settlement (McGrath et al. 1988). Also important are underlying physical factors such as water temperature, which affects gonad development and the timing of spawning (Avendaño \& Cantillánez 2013), wind patterns (Barria et al. 2012), wave exposure and water flow (Hunt \& Scheibling 1996).

In New Zealand, farming of the endemic greenlipped mussel Perna canaliculus is the largest aquaculture industry, with annual export earnings equating to US\$218 million. Uncertainty around seasonal and long-term patterns of availability of $P$. canaliculus spat directly affects the development of mussel farming, with years of lower-than-normal spat catches having led to adverse economic impacts on the industry since it began in the 1970s (Jeffs et al. 1999, South et al. 2017). Wild-caught spat in New Zealand have historically been sourced from 2 main regions, from which the spat are collected and then transported to mussel farms around the country. Around $70 \%$ of this supply is referred to as 'Kaitaia' spat, referring to a geographic location in northern New Zealand where mussel spat, adhering to various species of macroalgae and other flotsam, wash up onto beaches (Hickman 1976, Jeffs et al. 1999). The factors associated with the arrival of beach-cast Kaitaia spat are increasingly well understood (Alfaro 2006a, Jeffs et al. 2018), with storm events recognised as being particularly important (Alfaro et al. 2010).
By contrast, relatively little is known about the factors that drive the availability of the second main source of $P$. canaliculus spat, which provides much of the remaining $30 \%$ required by the industry. This source, completely independent of Kaitaia spat, comes from mussel-farming areas in New Zealand's top of the South Island (TOS), mainly from a subregion in Golden Bay (Fig. 1), and naturally settles onto fibrous ('Xmas tree') ropes that are suspended from surface lines (Fig. 2A,B). Although Kaitaia spat are an essential source for the industry, TOS-sourced spat reach harvest condition more quickly and provide a far greater annual crop yield (Fox 2003, Forrest \& Atalah 2017). Thus, in recent years there has been growing concern about an apparent reduction in spat catches in the TOS region. Currently the industry's expectations regarding TOS spat catching success are based mainly on operational experience, and historical catch records to some extent, but do not account for the underlying drivers of spatio-temporal variation in settlement. As such, better understanding of the factors influencing spat settlement is critical to industry growth. Such knowledge could potentially be used to forecast wild spat catches, assist in better management of the risk associated with spat settlement variability, and ultimately improve productivity.

In this study, we analysed long-term regional-scale $P$. canaliculus settlement data collected by the mussel industry, collated together with a range of relevant environmental variables, with the aim of understanding drivers of settlement and forecasting potential catches according to industry abundance criteria. We used gradient boosted regression trees, a machinelearning technique that enables efficient modelling and prediction in highly complex systems, to identify key drivers of $P$. canaliculus settlement and to forecast future patterns. As well as its direct relevance to an applied problem, the study more broadly provides insights into mussel spat settlement as an ecological process that underpins a globally significant marine industry.

\section{MATERIALS AND METHODS}

\subsection{Perna canaliculus spat settlement dataset and study areas}

Our study used datasets collected by the New Zealand Marine Farming Association, which contained mussel spat settlement monitoring data dating back to 1975 . During this period, data were collected con- 


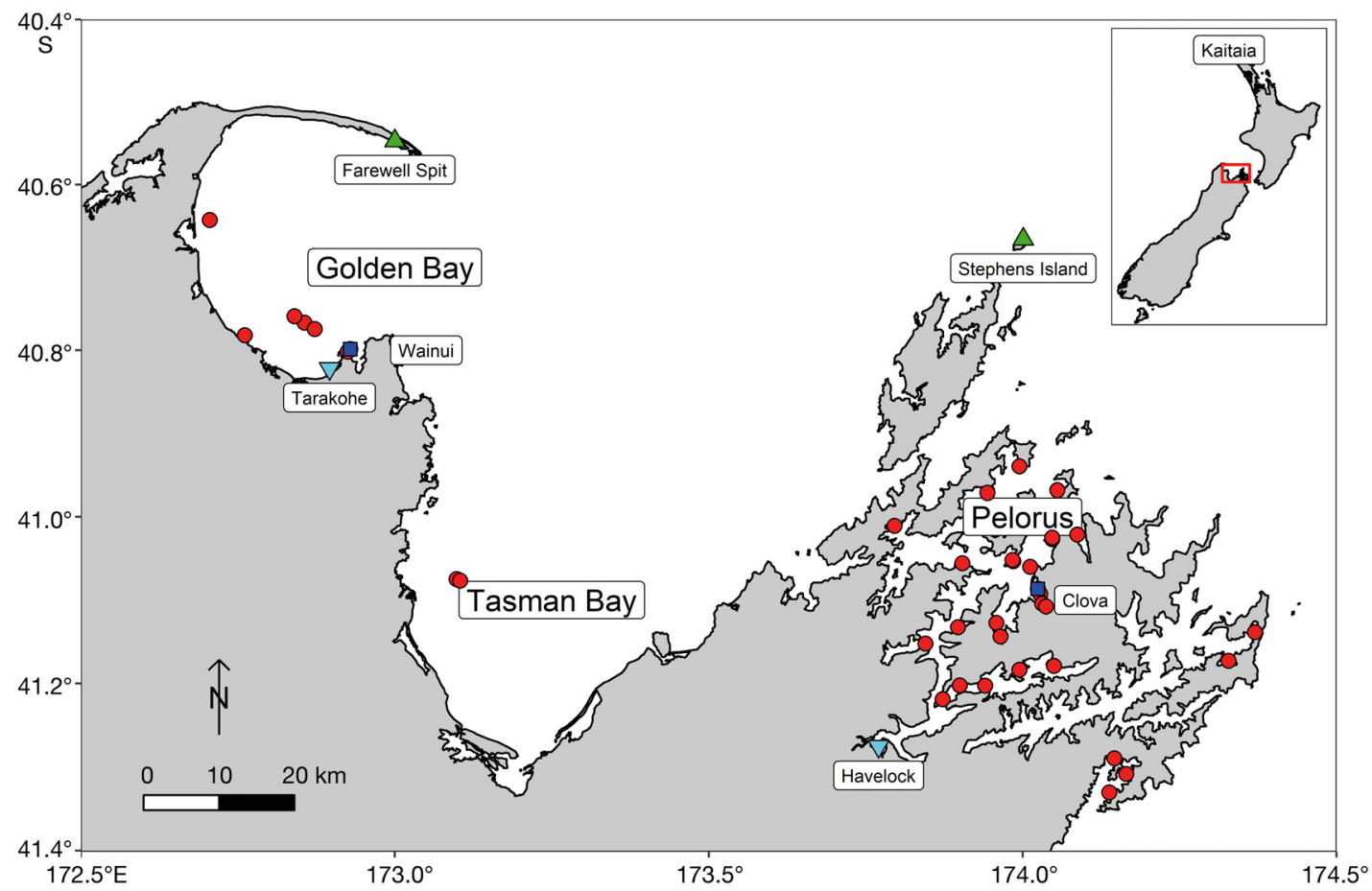

Fig. 1. The study area, in relation to New Zealand (inset), showing the main sub-regions relevant to this study: sampling stations (৩), climate stations (i.e. Farewell Spit and Stephens Island, $\mathbf{\Delta}$ ), tidal range stations (Tarakohe and Havelock, $\nabla$ ) and sites used for the predictive models (i.e. Wainui and Clova, $\square$ ). The inset also shows the location of Kaitaia, the area where the largest proportion of green-lipped mussel Perna canaliculus spat is obtained
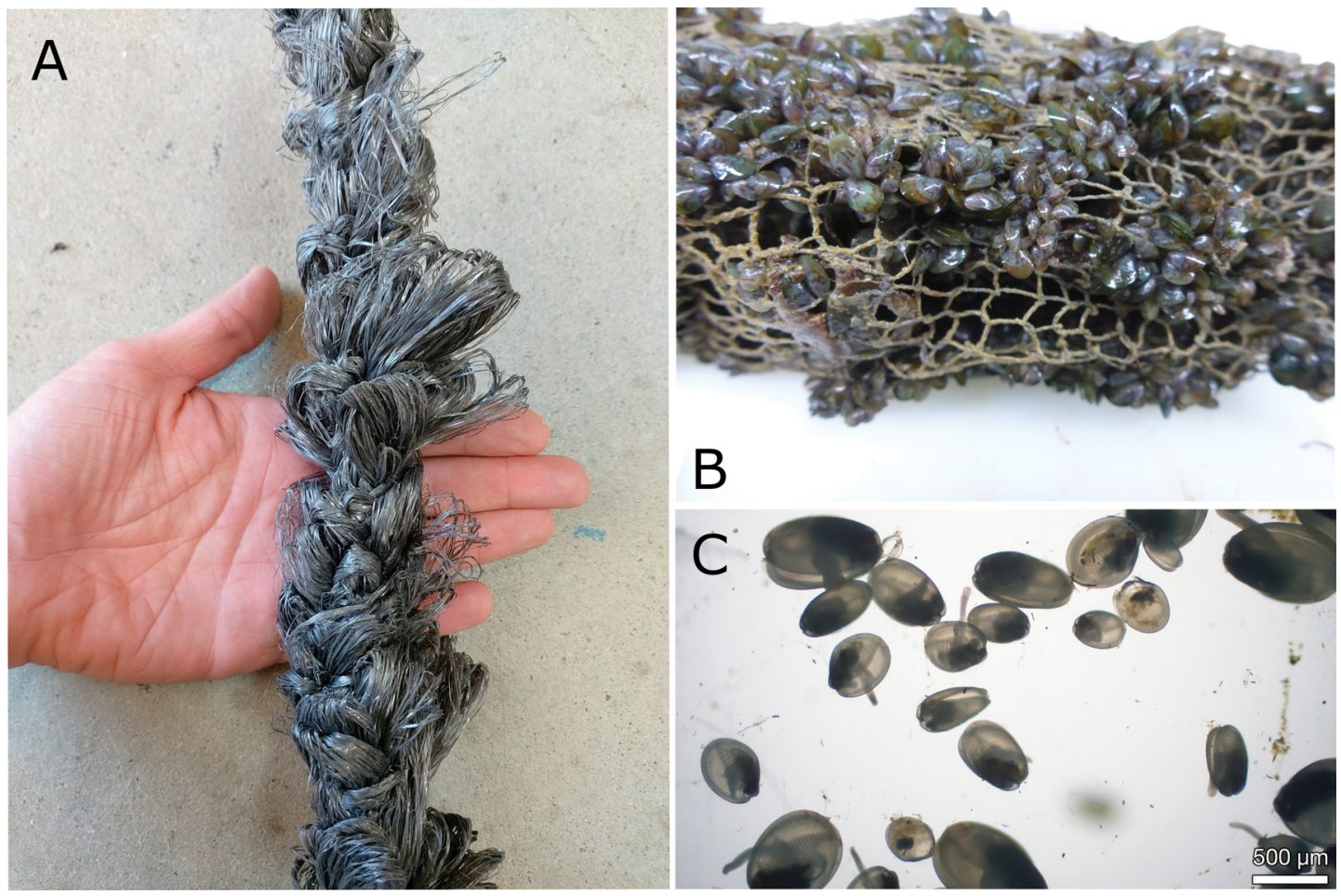

Fig. 2. (A) 'Xmas tree' rope used in collectors to sample green-lipped mussel Perna canaliculus spat and (B) a lifted spat monitoring line covered in green-lipped mussel spat. (C) Green-lipped mussel spat are retrieved from the 'Xmas tree' ropes after 1 wk and taken to the laboratory where they are counted using a binocular microscope. Photo credits: Natali Delorme, Paul South 
sistently throughout the year between 1993 and 2018; hence, this 25 yr subset was used in all of our analyses. Monitoring of Perna canaliculus settlement is ongoing and uses spat collectors consisting of $0.5 \mathrm{~m}$ sections of previously unused mussel industry 'Xmas tree' (Fig. 2A) polypropylene rope, deployed at multiple sites within 3 sub-regions across the TOS study area, namely Golden Bay, Tasman Bay and Pelorus Sound (Fig. 1). Golden Bay and Tasman Bay are positioned next to each other near the northwest corner of New Zealand's South Island (Fig. 1). Both bays are wide, shallow inlets and open to Cook Strait, which separates New Zealand's 2 main land masses. Pelorus Sound is an intricate system of drowned valleys in the Marlborough Sounds region, at the northeast corner of the South Island (Fig. 1). From its headwaters at Havelock, it is approximately $35 \mathrm{~km}$ to where its entrance opens to Cook Strait. Freshwater inflows near Havelock combined with diurnal tides are key drivers that influence salinity, temperature, sedimentation and productivity along the length of Pelorus Sound.

Industry monitoring involves weekly deployments of 1 collector per site for a $1 \mathrm{wk}$ period at varying water depths throughout the year, across a network of locations in all of the 3 study sub-regions. In the Golden Bay and Tasman Bay sub-regions, sampling effort is focused mostly between 3 and $6 \mathrm{~m}$ depth, whereas in Pelorus Sound it is between 2 and $15 \mathrm{~m}$ depth. After $1 \mathrm{wk}$, the collectors are retrieved and taken to a laboratory where all $P$. canaliculus spat (ca. $0.5 \mathrm{~mm}$ shell length) are removed from the rope by soaking them in a bleach solution, and counted by trained personnel using a binocular microscope. Samples are subdivided when spat abundance are $>2000$ per collector. In this paper, the term 'settlement' is used to describe these weekly mussel counts (Keough \& Downes 1982). By contrast, during industry spat operations, ropes are typically left in the water for ca. 2 to 4 wk, after which time settled mussels have a shell length of ca. 1 to $2 \mathrm{~mm}$ and are referred to hereafter as 'catch'.

Initial data exploration revealed geographic and temporal gaps in the dataset, especially in the earlier years of the monitoring programme and at certain sites. As such, while we describe overall regional spatial and temporal trends in $P$. canaliculus in the $25 \mathrm{yr}$ period from 1993 to 2018 for each of the 3 subregions $(\mathrm{n}=28697$ collectors in total), the statistical models focused on a subset of data for 2 key industry spat-catching sites: Wainui Bay in Golden Bay $(\mathrm{n}=$ 5606 collectors, depth range $=3-6 \mathrm{~m}$ ) and Clova Bay $(\mathrm{n}=4257$ collectors, depth range $=4-15 \mathrm{~m}$ ) in Pelorus Sound (Fig. 1). These 2 sites are regarded by industry as among the most productive in terms of spat catches, which was confirmed by initial exploration of the settlement data (see Section 3.1). Although a few other sites have high catches, they had insufficient temporal data for modelling purposes. The Wainui Bay site comprised 2 sampling locations that were pooled for the analyses, namely Wainui SE and Wainui NE, while Clova Bay comprised 4 sampling locations that were also pooled, namely Clova Bay, Clova NE, Manaroa and Crail Bay.

\subsection{Environmental data}

Site-specific environmental data for the $25 \mathrm{yr}$ modelled period were obtained for the 2 modelled sites (i.e. Wainui and Clova) from several sources (Table 1). Temperature data were extracted from the National Institute of Water and Atmospheric Research's National Climate Database service (Cliflo, https://cliflo. niwa.co.nz/), using the Farewell Spit station for Wainui and the Stephens Island station for Clova (Fig. 1). Cliflo data were obtained using the library Cliflor (Seers \& Shears 2015) in the software R (R Core Team 2018). Temperature measured at a $100 \mathrm{~cm}$ soil depth was used as a proxy for water temperature, as it had the highest correlation with sea surface temperature measured at a monitoring buoy in Tasman Bay $(r=0.96)$, compared with other temperature variables available from Cliflo. Temperature anomalies were calculated as the difference between raw data values and area-specific $25 \mathrm{yr}$ monthly averages. A positive 'Temperature anomaly' indicates the observed temperature was warmer than the $25 \mathrm{yr}$ monthly average, while a negative anomaly indicates the observed temperature was cooler.

Daily wind speed and average direction were also obtained from Cliflo. As the study region is influenced by a strong upwelling source along the West Coast driven by prevailing westerly winds (Shirtcliffe et al. 1990), we focused on across-shelf wind stress components (hereafter referred to as 'Westerly winds'), calculated by adding $30^{\circ}$ to the raw wind bearings to align them with the regional NNW-SSE continental shelf orientation (Zeldis et al. 2008). Wind stress was calculated as the product of the surface drag coefficient, the air density and the Euclidian distance of the $\mathrm{E}$ and $\mathrm{N}$ wind velocity components (Sharples \& Greig 1998). Negative and positive wind values indicate wind stress blowing from the NNW (westerly winds) and SSE (easterly winds), respectively.

Southern Oscillation Index (SOI, Trenberth 1984) data were obtained from https://crudata.uea.ac.uk/ 
Table 1. Description, source and summary statistics of environmental data used in the boosted regression tree models of green-lipped mussel Perna canaliculus spat at 2 key industry sites: Wainui and Clova

\begin{tabular}{|c|c|c|c|c|c|c|c|c|}
\hline Variable & Unit & Definition & Source & Site & Mean & Minimum & Maximum & $\mathrm{SD}$ \\
\hline Depth & $\mathrm{m}$ & $\begin{array}{l}\text { Depth below the sea } \\
\text { surface. }\end{array}$ & $\begin{array}{l}\text { Marine Farming Association } \\
\text { dataset (MFA, https:// } \\
\text { cawthron.shinyapps.io/ } \\
\text { BMOP/) }\end{array}$ & $\begin{array}{l}\text { Wainui } \\
\text { Clova }\end{array}$ & $\begin{array}{c}3.96 \\
10.76\end{array}$ & $\begin{array}{c}3.33 \\
4\end{array}$ & $\begin{array}{c}5.5 \\
15\end{array}$ & $\begin{array}{l}0.67 \\
4.23\end{array}$ \\
\hline SOI & unitless & $\begin{array}{l}\text { Southern Oscillation } \\
\text { Index lagged by one } \\
\text { month. }\end{array}$ & $\begin{array}{l}\text { Climatic Research Unit, } \\
\text { University of East Anglia } \\
\text { (https://crudata.uea.ac.uk/ } \\
\text { cru/data/soi/) }\end{array}$ & $\begin{array}{l}\text { Wainui } \\
\text { Clova }\end{array}$ & $\begin{array}{l}-0.04 \\
-0.05\end{array}$ & $\begin{array}{l}-3.04 \\
-3.13\end{array}$ & $\begin{array}{l}2.79 \\
2.91\end{array}$ & $\begin{array}{l}1.02 \\
1.05\end{array}$ \\
\hline Wind stress & $\mathrm{Pa}$ & $\begin{array}{l}\text { Across-shelf wind } \\
\text { stress anomaly. } \\
\text { Positive values coming } \\
\text { from SSE (easterly } \\
\text { winds) and negative } \\
\text { from the NNW } \\
\text { (westerly winds). }\end{array}$ & $\begin{array}{l}\text { New Zealand's National } \\
\text { Climate Database (Cliflo), } \\
\text { National Institute of Water } \\
\text { and Atmospheric Research } \\
\text { Ltd (NIWA, } \\
\text { https://cliflo.niwa.co.nz/) }\end{array}$ & $\begin{array}{l}\text { Wainui } \\
\text { Clova }\end{array}$ & $\begin{array}{l}0.001 \\
0.002\end{array}$ & $\begin{array}{l}-0.008 \\
-0.049\end{array}$ & $\begin{array}{l}0.014 \\
0.022\end{array}$ & $\begin{array}{l}0.003 \\
0.007\end{array}$ \\
\hline Tidal range & $\mathrm{m}$ & $\begin{array}{l}\text { Maximum tidal range } \\
\text { during sampling } \\
\text { period, calculated as } \\
\text { the difference between } \\
\text { maximum high tide } \\
\text { and minimum low tide } \\
\text { height in meters. }\end{array}$ & $\begin{array}{l}\text { Land Information New } \\
\text { Zealand (LINZ, } \\
\text { www.linz.govt.nz/sea/tides/ } \\
\text { tide-predictions). }\end{array}$ & $\begin{array}{l}\text { Wainui } \\
\text { Clova }\end{array}$ & $\begin{array}{l}2.83 \\
2.12\end{array}$ & $\begin{array}{c}2.3 \\
1.15\end{array}$ & $\begin{array}{c}3.7 \\
3\end{array}$ & $\begin{array}{l}0.16 \\
0.15\end{array}$ \\
\hline
\end{tabular}

cru/data/soi/. SOI is a measure of the large-scale pressure differential between the western and eastern tropical Pacific. Negative values of this index correspond to El Niño conditions, while positive SOI values coincide with La Niña episodes (Troup 1965). These episodes can have an important influence on climate, including year-to-year variability in wind patterns, temperature and rainfall. Minimum and maximum tidal ranges for the nearest port to each site (i.e. Tarakohe for Wainui and Havelock for Clova) were obtained from Land Information New Zealand (www.linz.govt.nz/sea/tides/tide-predictions).

\subsection{Statistical analysis}

Initial data exploration was conducted according to Zuur et al. (2010). P. canaliculus spat abundance data were standardised before all analyses to the number of individuals per metre of rope. The regional distribution of historical $P$. canaliculus settlement averaged across the 25 yr study period for individual sites was visualised using a bubble map, with average abundances represented as bubbles superimposed on the coordinate centroids of spat-catching sites. Long-term and seasonal trends in historical $P$. canaliculus settlement were visualised by plotting yearly and monthly mean catches $( \pm \mathrm{SE})$, respectively, through time for each of the 3 sub-regions (Golden Bay, Tasman Bay, Pelorus Sound).

Predictive models of settlement for the 2 best spatcatching areas (Wainui, Clova) used boosted regression trees (BRT, Elith et al. 2008, Greenwell et al. 2019), a machine-learning technique based on regression trees for modelling single response variables using several predictors (Leathwick et al. 2006). Regression tree methods recursively partition data into sets, each of which are simply modelled using regression methods. BRT is an ensemble method, meaning that a large number of relatively simple regression tree models are combined and averaged to give a model that generally outperforms conventional regression-based techniques with respect to their prediction accuracy. Other advantages of using a BRT approach include the ability to automatically handle interactions between predictors, to 
rank the predictors according to their relative contributions and to describe their potentially complex response curves. In regression tree analyses, nonconstant variation gives greater weight to data with higher variation, and therefore it is often desirable to transform the response variable (Segal 1988, De'ath \& Fabricius 2000). Hence, P. canaliculus abundance was $\log (x+1)$ transformed before the analyses to account for high right skewness and over-dispersion. We aggregated the total number of $P$. canaliculus spat per meter per week across Month within each Year, for each Depth and Site node. This approach reduced the space and time dimensions of the model and allowed for more accurate predictions, resulting in 482 observations for Wainui and 669 for Clova. Models were fitted using a Gaussian error distribution with 'Month', 'Year' and 'Depth' as continuous covariates to account for seasonal, inter-annual, and depth-related trends, respectively, whereas SOI, Wind and Temperature anomaly were lagged by 1 mo to imitate forecasting conditions. Predicted tidal range (in $\mathrm{m}$ ) was computed as the difference between maximum and minimum tidal height and included as a covariate. Depth was not included in any of the models due to the high imbalance in the data; however, patterns were visually explored. All covariates were uncorrelated $(\mathrm{r}<0.3$ for all pairs and variance inflation factors $<3$, Zuur et al. 2010), and were centred, scaled and transformed using the Box-Cox transformation before the analyses.

Forecasting of $P$. canaliculus spat abundances in relation to environmental conditions aimed to predict settlement 1 mo ahead. To test forecasting accuracy and provide independent test datasets, we used rolling forecasting cross-validation with a fixed window of 48 mo and a horizon of 1 mo ahead (Hyndman \& Athanasopoulos 2013). This technique trains models using 48 mo data subsets, predicts 1 mo ahead and then compares forecasted vs. observed values. Using this approach, the overall modelling used 48 test data subsets to obtain model parameters that minimised the mean-squared-error of forecasted values. Optimised parameters included the number of trees (between 100 and 1000), the minimum number of observations in the tree's terminal nodes and the model shrinkage parameter. Tree complexity was specified to allow up to 3-way interactions and main effects were visualised using partial plots. Final models were validated by inspecting the deviance residuals and presented as partial effects plots, which show the effect of each predictor variable conditional on others in the model. Results are presented as means of the number of individuals per metre of col- lector rope per week (ind. $\mathrm{m}^{-1} \mathrm{wk}^{-1}$ ) \pm 1 standard error of the mean, as a measurement of $P$. canaliculus settlement. All statistical analyses were performed with the software R using the ' $\mathrm{gbm}$ ' (Greenwell et al. 2019) and 'caret' (Kuhn et al. 2018) packages.

\section{RESULTS}

\subsection{Spatial patterns of Perna canaliculus settlement}

Perna canaliculus weekly settlement at any given site ranged from 0 to a maximum of 1328000 ind. $\mathrm{m}^{-1}$ $\mathrm{wk}^{-1}$, which was recorded in Wainui in December 1996. The overall mean was $1466( \pm 87)$, with regional spatial patterns (Fig. 3) revealing by far the greatest settlement at Golden Bay. Data aggregation within each spat catching sub-region across the $25 \mathrm{yr}$ period revealed a mean of $3224 \pm 260$ for Golden Bay, compared to $1275 \pm 126$ for Tasman Bay and $548 \pm 15$ for Pelorus Sound. Despite settlement being low in Pelorus Sound overall, it was relatively high at a small subset of sites within this sub-region, with the sites with the highest numbers of settled recruits being Kenepuru Sound (1614 \pm 317 , Fig. 3) and Clova Bay $(1200 \pm 86$, Fig. 3). In Tasman Bay, the top site had an average settlement of $1618 \pm 190$, which was similar to the top Pelorus sites (Fig. 3). By contrast, and consistent with industry experience, Wainui was by far the most productive site within Golden Bay with an overall mean settlement of $6149 \pm 904$. Settlement across water depths did not suggest any strong patterns within any of the 3 sub-regions (Fig. 4), with the only exception being an apparent lower settlement in surface waters in Golden Bay $(2 \mathrm{~m}$ depth, Fig. 4); however, the data were highly imbalanced in relation to depth $(\mathrm{n}=8,825$ and 186 for 2,4 and $6 \mathrm{~m}$ depth, respectively, Fig. 4).

\subsection{Temporal patterns of $P$. canaliculus settlement}

Over the $25 \mathrm{yr}$ period represented by the dataset, there was a large inter-annual variability in settlement across the 3 sub-regions (Fig. 5A). Historically, the greatest mean annual settlement was recorded at Golden Bay, with a record high in 1997 (mean $9489 \pm$ $5740)$, followed by relatively low settlement $(<2000)$ between 2000 and 2008 (Fig. 5A). By 2013, settlement recovered to a yearly mean of $7183 \pm 2515$, with a subsequent decline recorded in recent years, down to a mean of ca. 500 in 2015 (Fig. 5A). However, an 


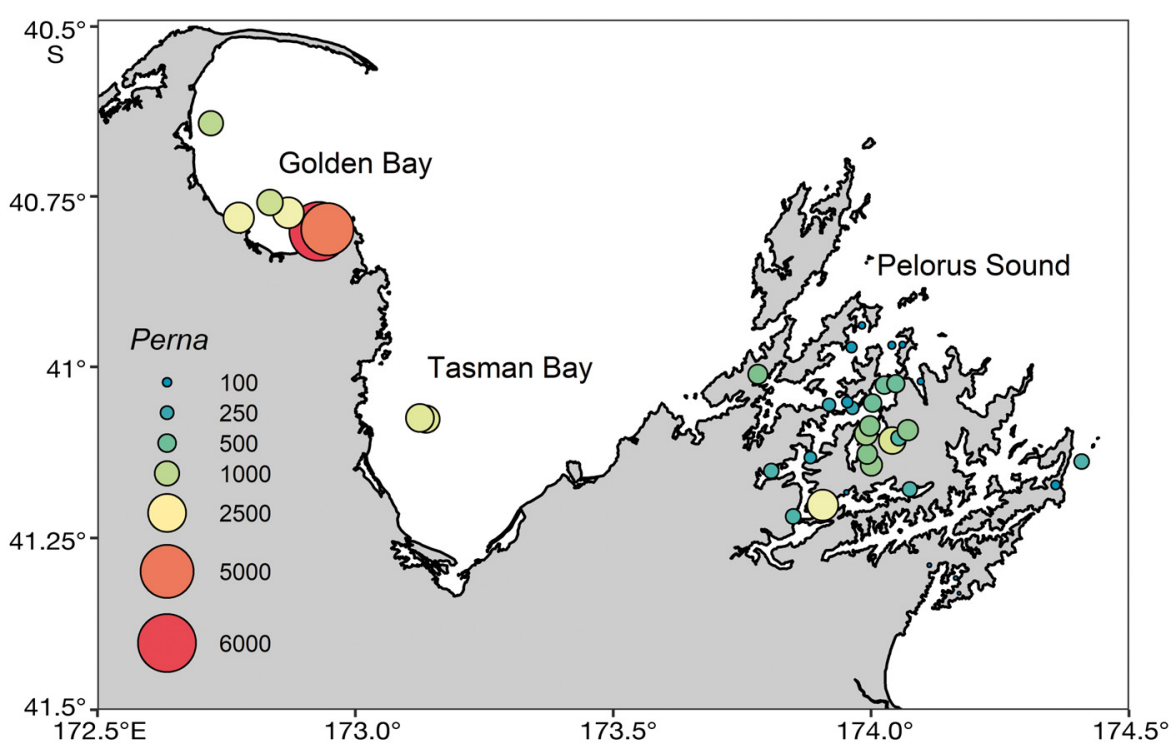

Fig. 3. Historical (1993-2018) average green-lipped mussel Perna canaliculus spat settlement (ind. $\mathrm{m}^{-1} \mathrm{wk}^{-1}$ ) aggregated across depths, months and years, within the study area at the top of South Island, New Zealand

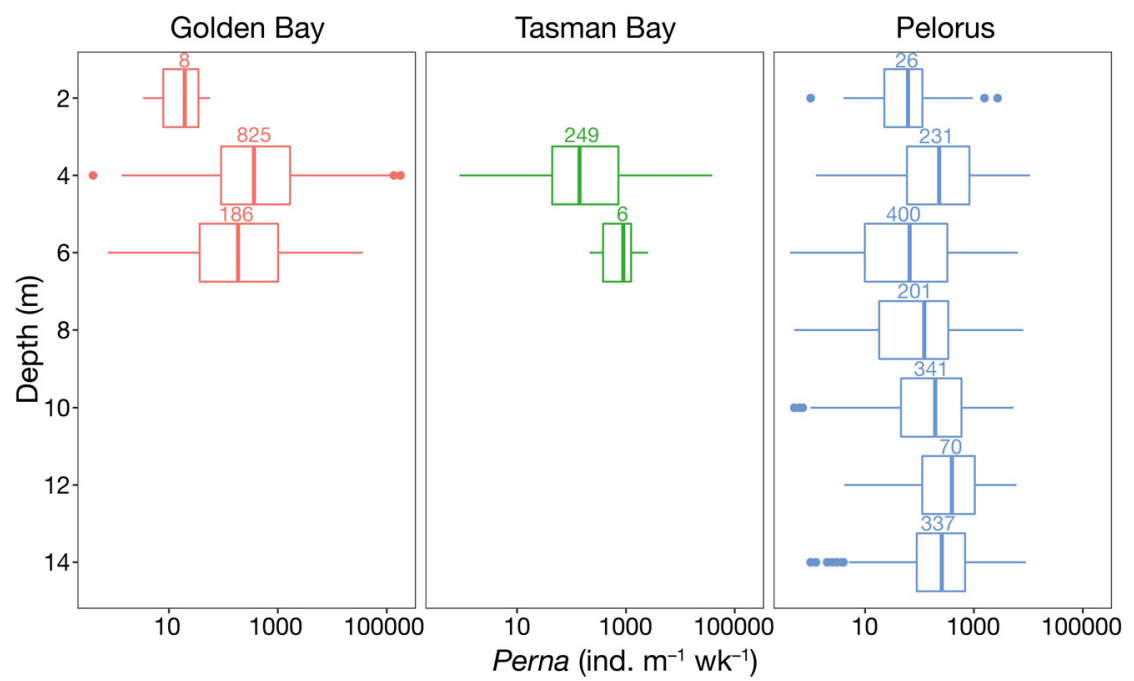

Fig. 4. Overall depth trend of Perna canaliculus spat settlement (ind. $\mathrm{m}^{-1} \mathrm{wk}^{-1}$ ) for Golden Bay, Tasman Bay and Pelorus Sound, aggregated across month and year within each sub-region. Sample size for each depth is shown above each box. Lines in boxes are medians, boxes are the interquartile range, and whiskers extend to the lowest or highest data point $\leq 1.5 \times$ the interquartile range. Dots are outliers

apparent recovery in settlement in Golden Bay has been evident in the last 3 years, with an annual mean of $2168 \pm 450$ in 2018. In Tasman Bay, yearly settlement was markedly less than in Golden Bay, although considerable inter-annual variability was also evident from when records began in 1999. Settlement peaked in 2012 and 2013 (3968 \pm 2697 and $2447 \pm 1616$, respectively), followed by a subsequent annual decline (Fig. 5A). However, as was also the case for Golden Bay, there has been a recovery in mean values in the last 3 years. In Pelorus Sound, yearly settlement was also markedly less than in Golden Bay, and yearly peaks were the lowest of the 3 sub-regions. The highest settlement levels were recorded in 2008 and $2010(1680 \pm 304$ and $1364 \pm 331$, respectively), followed by a decline to $<700$ since then (Fig. 5A).

Seasonal patterns in monthly settlement had a distinctive peak at the end of the Austral summer through to early autumn (i.e. between March and May, Fig. 5B). However, this seasonal pattern slightly varied at a regional scale. Sites in the western sub-regions (i.e. Golden and Tasman bays) had peak spat settlement in April and May, whereas Pelorus sites had a less pronounced peak that was confined to March and April (Fig. 5B). Additionally, there was a secondary peak in monthly settlement during December and January in Golden Bay, which was not evident in the other 2 regions (Fig. 5B).

\subsection{Predictive model of \\ $P$. canaliculus settlement in relation to environmental drivers}

The BRT model for Wainui explained $85 \%$ of the variability in the data (Table 2) and had a high forecasting ability as indicated in the 1 mo ahead walk-forward validation (Table $2, \mathrm{R}^{2}=$ 0.83). Among the predictor variables, Month of the year ranked first in terms of relative influence $(30 \%)$, followed by SOI $(17 \%)$, Year $(17 \%)$, Winds $(12 \%)$, Temperature anomaly (11\%), Tidal range (9\%) and Depth (4\%, Fig. 6, Table 2). Partial effect plots (Fig. 6) predicted settlement to be greatest at Wainui in April and May. SOI, positive temperature anomaly and easterly winds were positively correlated with settlement, whereas settlement was predicted to be highest during periods of tidal height range around $3 \mathrm{~m}$, which correspond to greater than average tides (Fig.6). 
A

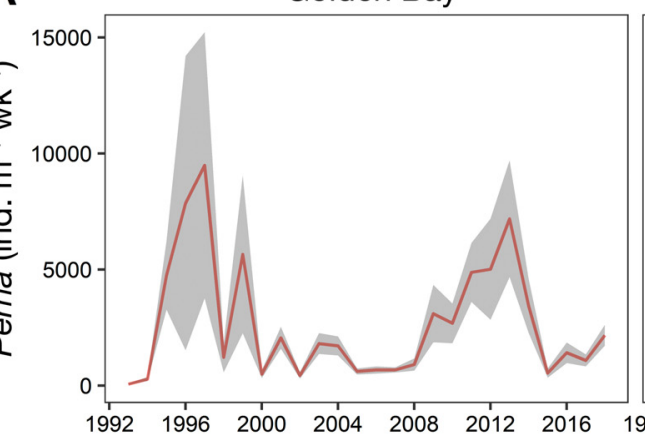

Golden Bay

Tasman Bay
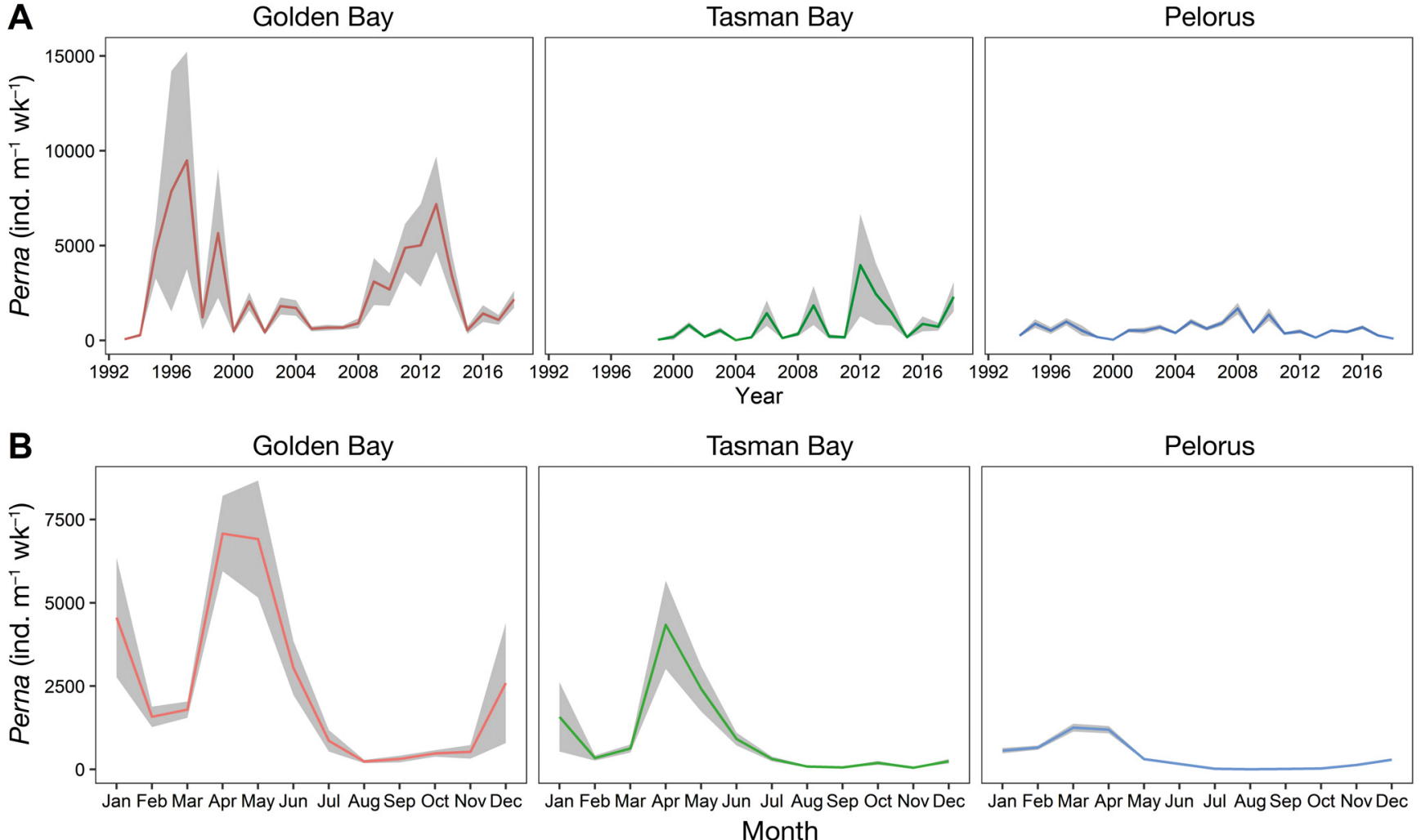

Fig. 5. (A) Long-term and (B) seasonal trend in mean Perna canaliculus spat settlement (ind. $\mathrm{m}^{-1} \mathrm{wk}^{-1}$ ) for Golden Bay, Tasman Bay and Pelorus Sound. The lines are yearly and monthly averages, respectively, \pm SE (grey shading) aggregated across depths and sites within each sub-region. Sample sizes as follows: Golden Bay $(\mathrm{n}=1059)$, Tasman Bay $(\mathrm{n}=258)$ and Pelorus Sound $(n=1652)$

Table 2. Relative influence (\%) of predictor variables, $\mathrm{R}^{2}$ values for fitted and forecasted data and number of observations (n) for the boosted regression tree models fitted using timeseries cross-validation on data from Wainui Bay in Golden Bay and Clova Bay in Pelorus Sound

\begin{tabular}{|lcr|}
\hline \multirow{2}{*}{ Variable } & \multicolumn{2}{c|}{ Relative influence (\%) } \\
& Wainui & Clova \\
\hline Month & 29.98 & 49.75 \\
Southern Oscillation Index & 17.17 & 8.94 \\
Year & 17.13 & 14.80 \\
Winds & 11.85 & 9.18 \\
Temperature anomaly & 11.10 & 6.83 \\
Tidal range & 8.86 & 7.06 \\
Depth & 3.91 & 3.45 \\
$\mathrm{R}^{2}$ fitted & 0.85 & 0.89 \\
$\mathrm{R}^{2}$ forecasted & 0.83 & 0.52 \\
$\mathrm{n}$ & 479 & 699 \\
\hline
\end{tabular}

The BRT model for Clova Bay explained $89 \%$ of the variability in the data (Table 2) and had a moderate forecasting ability as indicated in the 1 mo ahead walk-forward validation $\left(\mathrm{R}^{2}=0.52\right.$, Table 2$)$. Similarly, Month of the year had the highest relative influ- ence $(50 \%)$ in the Clova model, followed by Year $(15 \%)$, Winds and SOI $(9 \%)$, Tidal range and Temperature anomaly $(7 \%)$, and lastly depth $(3 \%)$. The model partial plots (Fig. 6) predicted highest settlement in March and April, at depths shallower than 6 $\mathrm{m}$. Highest settlement was associated with positive temperature anomalies and easterly winds (i.e. positive wind stress values), whereas the effect of SOI was highest around values of zero. Overall, predicted settlement at Wainui in relation to categorical industry scales for spat-catching performance was $65 \%$ Poor, 19\% Moderate and 16\% Good (Fig. 7, Table 3). In Clova Bay, predicted settlement was categorised considerably poorer, with $82 \%$ Poor, $16 \%$ Moderate and only $2 \%$ Good (Fig. 7, Table 3).

\section{DISCUSSION}

We used a unique long-term dataset spanning $25 \mathrm{yr}$ to identify regional spatio-temporal patterns of Perna canaliculus spat settlement. In addition to strong seasonal patterns, boosted regression models identified 

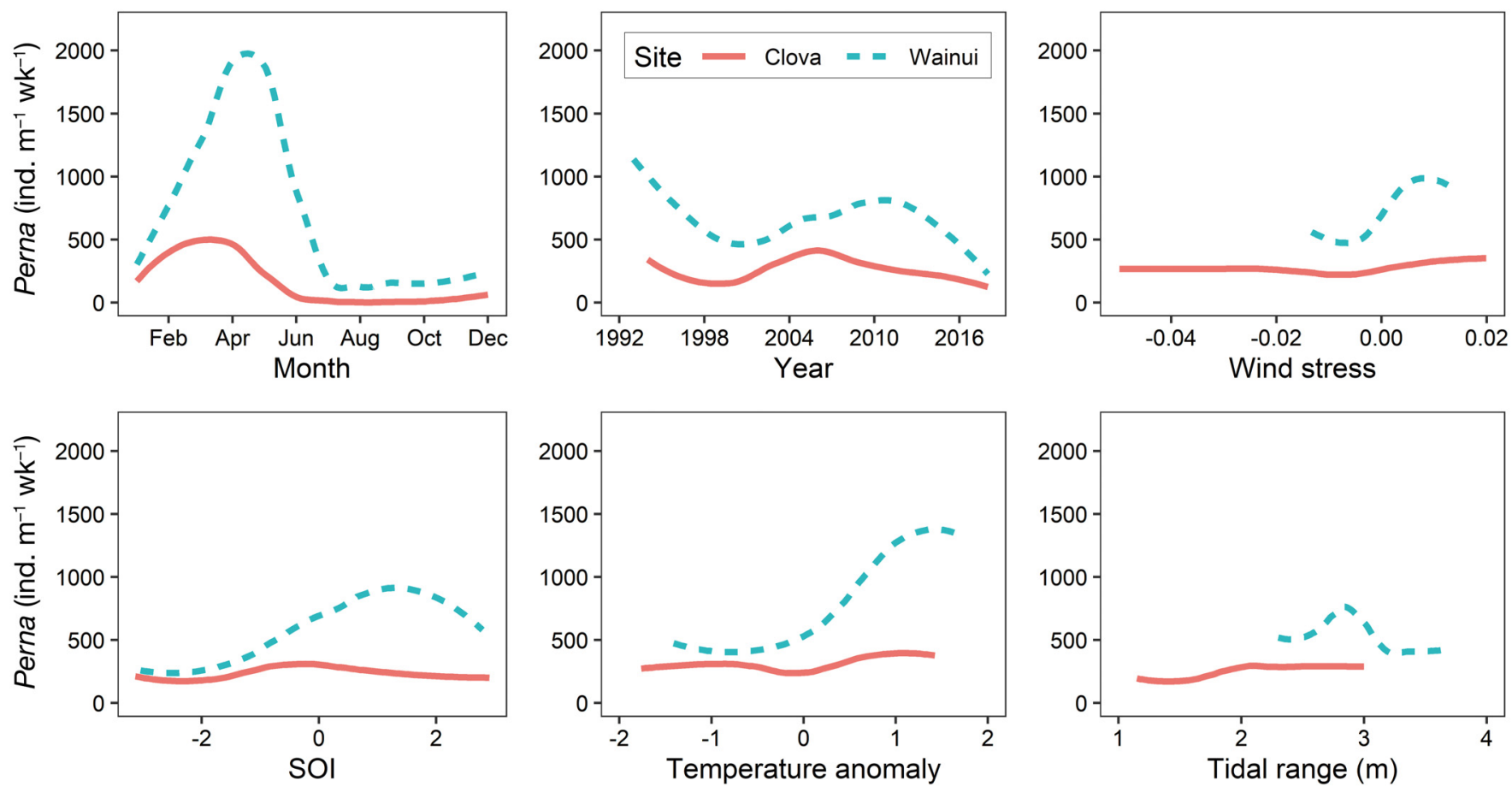

Fig. 6. Partial dependence plots for the 6 most important predictor variables for the boosted regression tree models fitted using timeseries cross-validation on data from Wainui Bay $(\mathrm{n}=479)$ and Clova Bay in Pelorus Sound $(\mathrm{n}=699)$. SOI: Southern Oscillation Index

\section{A) Wainui}

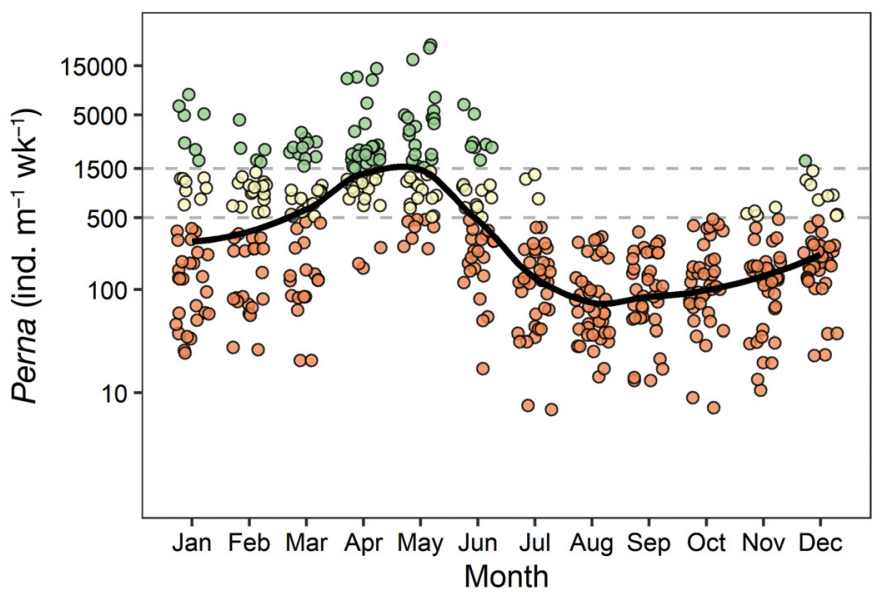

B) Clova

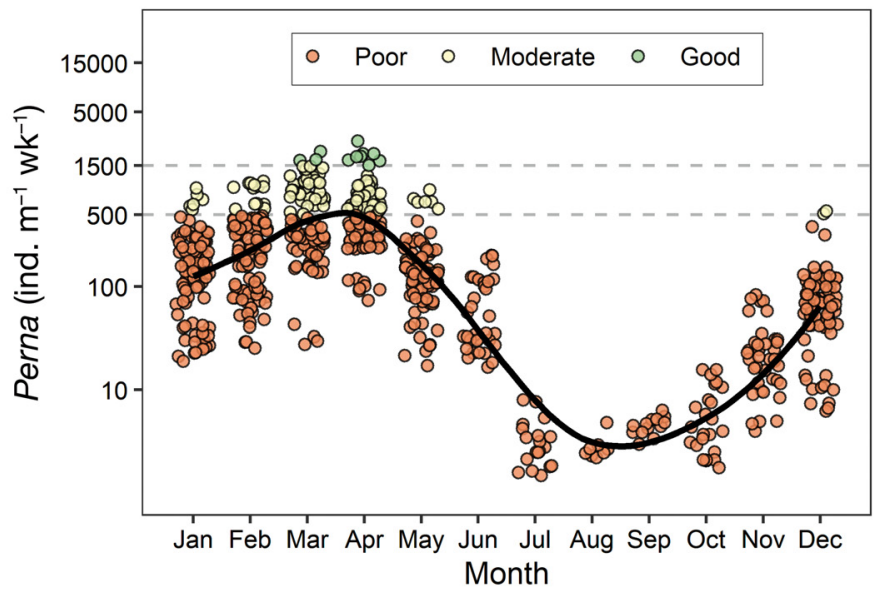

Fig. 7. Monthly model predictions of green-lipped mussel Perna canaliculus spat abundance (ind. $\mathrm{m}^{-1}$ of rope) based on the $25 \mathrm{yr}$ time series data and accounting for the effects of modelled environmental variables. A loess smoother (black line) was added to aid visual interpretation. Abundances are shown in relation to industry categorical scales for spat catching performance (dashed lines) (Poor: 0-500; Moderate: 500-1500; Good: $>1500$ ind. $\mathrm{m}^{-1} \mathrm{wk}^{-1}$ ) for each of 2 key industry spat-catching sites: (A) Wainui Bay and (B) Clova Bay

environmental drivers for settlement, including positive temperature anomalies, easterly winds, periods of large tidal range and SOI values associated with $\mathrm{La}$ Niña episodes. A critical part of sustaining a productive and profitable shellfish industry internationally is securing sufficient spat for stocking grow-out sites. In this context, machine-learning models like the one presented here allow forecasting of the supply of spat based on an understanding of environmental conditions driving settlement. Such tools enable operational decisions that can contribute to upscaling spat volume and securing industry production. Limits on spat supply at the start of the production chain can translate in important 'downstream' effects on indus- 
Table 3. Boosted regression tree model monthly predictions of percentage of greenlipped mussel Perna canaliculus spat settlement abundances within each of 3 industry performance categories for spat catching, at each of the 2 key spat catching sites: Wainui and Clova. Empty cells are zero. Poor: 0-500; Moderate: 500-1500; Good: $>1500$ ind. $\mathrm{m}^{-1} \mathrm{wk}^{-1}$

\begin{tabular}{|c|c|c|c|c|c|c|c|c|c|c|c|c|c|}
\hline \multirow[t]{2}{*}{ Site } & \multirow{2}{*}{ Category } & \multicolumn{12}{|c|}{ - Month } \\
\hline & & 1 & 2 & 3 & 4 & 5 & 6 & 7 & 8 & 9 & 10 & 11 & 12 \\
\hline \multirow[t]{3}{*}{ Wainui } & Poor & 64 & 5 & 43 & 7 & 19 & 53 & 92 & 1 & 1 & 1 & 9 & 79 \\
\hline & Moderate & 19 & 39 & 4 & 39 & 33 & 28 & 8 & & & & 1 & 19 \\
\hline & Good & 17 & 12 & 26 & 55 & 48 & 2 & & & & & & 2 \\
\hline \multirow[t]{3}{*}{ Clova } & Poor & 93 & 86 & 54 & 5 & 93 & 1 & 1 & 1 & 1 & 1 & 1 & 97 \\
\hline & Moderate & 7 & 14 & 43 & 42 & 7 & & & & & & & 3 \\
\hline & Good & & & 3 & 8 & & & & & & & & \\
\hline
\end{tabular}

try profitability. In the face of the relatively limited available coastal aquaculture space and increasing market demand for seafood, the shellfish industry needs to apply advanced technologies and to make knowledge-driven management decisions that allow it to optimise production.

\subsection{Spatio-temporal patterns in $P$. canaliculus settlement}

Large inter-annual and spatial variability in spat settlement, such as evident in the data analysed here, is an intrinsic characteristic of mussels and other benthic invertebrates (Thorson 1950, Porri et al. 2006, Atalah et al. 2017). The magnitude of spatio-temporal variation in the present study was consistent with other regional studies showing orders of magnitude variability in mussel settlement densities (Connolly et al. 2001, Garcia et al. 2003, Broitman et al. 2008, Demello \& Phillips 2011, Atalah et al. 2017).

Although overall settlement in the present study was greatest in the western sub-regions (Golden and Tasman bays), in Pelorus Sound there were marked differences among sites within the same bays. These spatial patterns are of considerable regional interest, but also perplexing in that there are no known significant adult $P$. canaliculus wild populations in the study region; therefore, the source populations of larvae are unknown. Given a larval duration of up to 4 wk in P. canaliculus (Jeffs et al. 1999), it may be the case that larvae are advected from outside the study area, and that hydrological or other conditions within the region favour the settlement and recruitment of larvae relatively consistently in a few key locations. Another possibility is that the broodstock are mussels growing on the farms themselves. Various approaches have been considered as a means of source tracking larval origin (e.g. hydrodynamic model back-tracking, population genetics), but none have been fully explored (Dunphy et al. 2011).

There was an overall lack of effect of depth on P. canaliculus settlement, with depth having little relative importance in both predictive models $(<4 \%)$, which generally aligns with previous studies conducted in New Zealand. Hayden (1995) found that there was large spatial variability in the effect of depth on mussel settlement in Pelorus. Similarly, another study that used a similar methodology in the same region found a lack of a depth-related pattern in $P$. canaliculus settlement (Meredyth-Young \& Jenkins 1978). By contrast, the effect of depth was size-dependent in Kaitaia, with large spat being more abundant in deeper waters, possibly due to secondary movement (Alfaro 2006b). This contrasts with the typical pattern of marked decreases in settlement with increasing depth that have been described for $\mathrm{My}_{\mathrm{y}}$ tilus galloprovincialis in the study region (MeredythYoung \& Jenkins 1978, Atalah et al. 2017). Depth differences are generally associated with larval vertical distribution patterns in relation to water column characteristics, such as the thermocline/halocline depth (Dobretsov \& Miron 2001). The lack of clear depth-related patterns of settlement highlights that this process can vary regionally within the same species, which is consistent with the variability in depth trends among sites and seasons described for many other mussel species (Rajagopal et al. 1998, Garcia et al. 2003, Holthuis et al. 2015).

Although there was no overall long-term trend over the $25 \mathrm{yr}$ time series of our dataset, there was a consistent late summer to autumn settlement peak (March to May depending on sub-region), which coincides with the main spawning period of $P$. canaliculus in the region (Buchanan 2001). This reproductive seasonality is a common pattern in many mussel species and is related to increases in water temperature and food availability during summer and autumn (Cáceres-Martínez \& Figueras 1997). These temporal and seasonal patterns differ substantially to those described for Kaitaia spat in Northern New Zealand. Kaitaia spat settlement appears to be less variable among years, with settlement peaking in late winter (Alfaro 2006a). This contrasting seasonality between Kaitaia and TOS spat settlement sug- 
gests important regional differences in the reproductive behaviour of adult mussel populations, which in turn makes TOS spat crucial for the industry during periods of low availability of Kaitaia spat.

\subsection{Environmental drivers and predictive models}

In the present study, no single environmental variable had a strong influence on settlement patterns, and it is likely that other unmeasured factors were important, such as food availability, water column physico-chemical properties, larval abundance and secondary settlement (South et al. 2017).

However, when considered together, the measured environmental variables had a considerable relative influence in the models $(52 \%$ and $37 \%$, for Wainui and Clova, respectively). At Wainui, P. canaliculus settlement was positively correlated with positive SOI values, indicative of La Niña conditions. La Niña events in New Zealand are characterised by an increased prevalence of north-easterly winds, which are associated with warmer than normal sea surface temperatures (Tenzer \& Wiart 2014). This is consistent with the weaker positive effect of temperature anomaly and easterly winds; hence, increased temperature and easterly winds during La Niña years may explain the observed positive relationship between SOI and settlement, and could account for some of the marked inter-annual variability. A weak positive effect was also attributed to larger than average tidal ranges, which potentially serve as proxies for increased water movement. In small-scale experiments larval settlement has been shown to be greater with increased water movement, most probably due to a greater supply of larvae (Alfaro 2005), as has the retention of larger mussel spat (Hayden \& Woods 2011).

Despite the highly variable nature of the data, and the weak individual effects of environmental drivers, the models for the 2 key spat-catching locations nonetheless provided very good forecasting ability of $P$. canaliculus spat settlement 1 mo ahead, particularly at Wainui $\left(\mathrm{R}^{2}=0.87\right)$ relative to Clova Bay $\left(\mathrm{R}^{2}=\right.$ 0.52). The best predictor for forecasting settlement was Month of the year, highlighting the strong seasonal effect with a $P$. canaliculus settlement peak over March to May, depending on sub-region. As a predictor, Month of the year will reflect an integration of the full suite of measured and unmeasured predictor variables. The latter may include variables such as the timing of adult $P$. canaliculus reproduction and seasonal fluctuations in environmental fac- tors that affect reproductive success or the fitness of larvae and recruits, such as nutrient inputs and phytoplankton quantity and composition (Mackenzie 2004, MacKenzie \& Adamson 2004).

\subsection{Management implications}

A marked interannual variability in settlement, and the relative influence of Year in the BRT models, highlights an apparent random element to mussel settlement and subsequent spat catch in some years in the study region. Nonetheless, the month-bymonth predictive models for Wainui and Clova, as well as the overall regional trends, can be used to guide farm management practices, such as the location and timing of deployment of $P$. canaliculus spat collection ropes to optimise catches. These seasonal patterns are predicted to oscillate in response to environmental drivers, with optimal settlement conditions predicted for warmer than average periods of time, easterly winds, periods with large tidal ranges and SOI values associated with La Niña episodes. These predictive patterns are likely to apply to nearby locations within these 2 sub-regions; however, as mentioned above, they are very distinct from those described for Kaitaia spat in northern New Zealand (Alfaro et al. 2010). The Wainui and Clova models require temperature, wind, tidal height and SOI data, which are already continually measured by climate stations and can be obtained from the web, therefore providing a very cost-efficient way to estimate potential $P$. canaliculus spat catches. Forecast model outputs can be displayed interactively in a web application, such as the one created by Atalah et al. (2017) for forecasting over-settlement of P. canaliculus spat by blue mussels $M$. galloprovincialis (https://cawthron.shinyapps.io/BMOP/). Displaying live data on a web application enables the mussel aquaculture industry to view forecasted $P$. canaliculus settlement, hence potential catches, in real-time.

The models for Wainui and Clova highlighted March to May as the period of the year when settlement levels are most likely to be optimal (see Fig. 7). Given a typical lag of 2 to 4 wk between catch rope deployment and spat catch harvest, an optimal settlement period across March to late May would roughly translate to a spat catch optimum over May to July. However, because Golden Bay is an area of high ecological, recreational and cultural value, spat-catching activities are regulated by the local government, with permit conditions restricting them to the period between 1 November and 30 April. Hence, it appears 
likely that this current restriction means that the best spat-catching period is being missed.

Of course, even though the sites of peak settlement are also those considered by the industry to be the best for spat catching, the settlement data presented here will not necessarily directly translate to industry catches in a quantitative sense. Many factors will operate to alter the relationship between early settlement success and subsequent spat catches. As well as factors like predation pressure and biofouling (Peteiro et al. 2010, South et al. 2017), mussel spat in the early post-settlement phase also have the ability to detach from the substratum and off-migrate to secondary settlement sites; a process observed for a range of species, including $P$. canaliculus in New Zealand (Buchanan \& Babcock 1997, Hayden \& Woods 2011, South 2016, South et al. 2017). Several New Zealand studies report $P$. canaliculus losses in the order of $80 \%$ in the first few weeks and months after settlement (Hayden \& Woods 2011, South 2016). As such, early settlement data have the potential to greatly overestimate the potential density of recovered spat catch for industry grow-out.

On the other hand, the deployment of spat rope for $1 \mathrm{wk}$ in the present study is short compared to the duration of time for which spat ropes are deployed for industry catching operations. As such, the accumulated spat densities may be greater under operational conditions, meaning that settlement densities after 1 wk may in fact underestimate subsequent catch success. Despite the range of processes that might affect the relationship between initial settlement and spat catch, early research at sites in the Pelorus Sound sub-region revealed reasonably strong and generally significant positive correlations between settlement at $1 \mathrm{wk}$ and after 8 and $12 \mathrm{wk}$, although this relationship was not always consistent and exhibited some degree of inter-annual variability (Hayden 1995).

\section{CONCLUDING REMARKS}

Here, using Perna canaliculus as an example, we have shown that settlement of shellfish spat can be forecasted 1 mo ahead with moderate to excellent prediction accuracy, based on time of year and environmental conditions 1 mo prior to collection. Given the potential for predictive modelling to forecast settlement, this study highlights the importance of developing monitoring programmes to build up longterm datasets. These programmes could capitalise on regional-scale environmental and production data already existent for many coastal farming areas and production systems. In the long term, these databases could be used to build predictive models, such as presented here. Key to this approach is the commitment to collect and maintain production and onfarm environmental databases. Such databases are not only relevant to mussel spat settlement but will future-proof the industry against the emergence of other issues impacting production, such as pest and diseases, spat retention or mortality events. The lack of adequate environmental and baseline production data can represent a major block for dealing with operational challenges, such as spat availability, experienced by many shellfish sectors. Addressing this shortcoming, with approaches such as described here, will enable better operational management and facilitate the upscaling of production.

Data archive. Mussel settlement data can be visualised at https://cawthron.shinyapps.io/BMOP/ and all R scripts used for the analyses are available at https://github.com/jatalah/ perna_recruitment.

Acknowledgements. We thank the New Zealand Marine Farming Association for providing the spat dataset and for insightful discussions about mussel spat settlement dynamics and spat catching operations. We are also grateful to Paul South for helpful review comments on the draft manuscript. This study was funded by the Ministry for Business Innovation and Employment Strategic Science Investment Fund Cawthron Institute Science Platform - Shellfish Aquaculture CAWX1801.

\section{LITERATURE CITED}

Alfaro AC (2005) Effect of water flow and oxygen concentration on early settlement of the New Zealand greenlipped mussel, Perna canaliculus. Aquaculture 246: 285-294

Alfaro AC (2006a) Population dynamics of the green-lipped mussel, Perna canaliculus, at various spatial and temporal scales in northern New Zealand. J Exp Mar Biol Ecol 334:294-315

Alfaro AC (2006b) Tidal migration influences the zonation of grazing snails (Turbo smaragdus) in a mangrove-seagrass estuary, Northern New Zealand. Estuaries Coasts 29:731-736

Alfaro AC, McArdle B, Jeffs AG (2010) Temporal patterns of arrival of beachcast green-lipped mussel (Perna canaliculus) spat harvested for aquaculture in New Zealand and its relationship with hydrodynamic and meteorological conditions. Aquaculture 302:208-218

Atalah J, Rabel H, Forrest BM (2017) Modelling long-term recruitment patterns of blue mussels Mytilus galloprovincialis: a biofouling pest of green-lipped mussel aquaculture in New Zealand. Aquacult Environ Interact 9:103-114

Avendaño M, Cantillánez M (2013) Reproductive cycle, collection and early growth of Aulacomya ater, Molina 1782 (Bivalvia: Mytilidae) in northern Chile. Aquacult Res 44: $1327-1338$ 
Barria A, Gebauer P, Molinet C (2012) Spatial and temporal variability of mytilid larval supply in the Seno de Reloncavi, southern Chile. Rev Biol Mar Oceanogr 47: 461-473

Bownes SJ, McQuaid CD (2009) Mechanisms of habitat segregation between an invasive and an indigenous mussel: settlement, post-settlement mortality and recruitment. Mar Biol 156:991-1006

Broitman BR, Blanchette CA, Menge BA, Lubchenco J and others (2008) Spatial and temporal patterns of invertebrate recruitment along the west coast of the United States. Ecol Monogr 78:403-421

Buchanan S (2001) Measuring reproductive condition in the Greenshell ${ }^{\mathrm{TM}}$ mussel Perna canaliculus. NZ J Mar Freshw Res 35:859-870

Buchanan S, Babcock R (1997) Primary and secondary settlement by the greenshell mussel Perna canaliculus. J Shellfish Res 16:71-76

Cáceres-Martínez J, Figueras A (1997) Mussel (Mytilus galloprovincialis Lamarck) settlement in the Ria de Vigo (NW Spain) during a tidal cycle. J Shellfish Res 16:83-85

* Cáceres-Martínez J, Figueras A (1998) Distribution and abundance of mussel (Mytilus galloprovincialis Lmk) larvae and post-larvae in the Ria de Vigo (NW Spain). J Exp Mar Biol Ecol 229:277-287

Connolly SR, Menge BA, Roughgarden J (2001) A latitudinal gradient in recruitment of intertidal invertebrates in the northeast Pacific Ocean. Ecology 82:1799-1813

* De'ath G, Fabricius KE (2000) Classification and regression trees: a powerful yet simple technique for ecological data analysis. Ecology 81:3178-3192

* Demello R, Phillips NE (2011) Variation in mussel and barnacle recruitment parallels a shift in intertidal community structure in the Cook Strait region of New Zealand. Mar Freshw Res 62:1221-1229

Víaz C, Figueroa Y, Sobenes C (2014) Seasonal effects of the seeding on the growth of Chilean mussel (Mytilus edulis platensis, d'Orbigny 1846) cultivated in central Chile. Aquaculture 428-429:215-222

* Dobretsov SV, Miron G (2001) Larval and post-larval vertical distribution of the mussel Mytilus edulis in the White Sea. Mar Ecol Prog Ser 218:179-187

* Dunphy BJ, Millet MA, Jeffs AG (2011) Elemental signatures in the shells of early juvenile green-lipped mussels (Perna canaliculus) and their potential use for larval tracking. Aquaculture 311:187-192

Elith J, Leathwick JR, Hastie T (2008) A working guide to boosted regression trees. J Anim Ecol 77:802-813

Forrest BM, Atalah J (2017) Significant impact from blue mussel Mytilus galloprovincialis biofouling on aquaculture production of green-lipped mussels in New Zealand. Aquacult Environ Interact 9:115-126

Fox SP (2003) The growth of cultured Perna canaliculus in Pelorus Sound, New Zealand: the importance of spat origin, environment, and time of harvest. PhD thesis, University of Canterbury

Fuentes J, Molares J (1994) Settlement of the mussel Mytilus galloprovincialis on collectors suspended from rafts in the Ria de Arousa (NW of Spain): annual pattern and spatial variability. Aquaculture 122:55-62

* Garcia EG, Thorarinsdottir GG, Ragnarsson SA (2003) Settlement of bivalve spat on artificial collectors in Eyjafjordur, North Iceland. Hydrobiologia 503:131-141

Greenwell B, Boehmke B, Cunningham J, GBM Developers (2019) gbm: Generalized Boosted Regression Mod- els. R package version 2.1.5. https://CRAN.R-project. org/package $=$ gbm

Hair C, Bell J, Doherty P (2002) The use of wild-caught juveniles in coastal aquaculture and its application to coral reef fishes. In: Stickney RR, McVey JP (eds) Responsible marine aquaculture. CAB International, Wallingford, p 327-353

Hayden BJ (1995) Factors affecting recruitment of farmed greenshell mussels, Perna canaliculus (Gmelin) 1791, in Marlborough Sounds. PhD thesis, University of Otago

Hayden BJ, Woods CMC (2011) Effect of water velocity on growth and retention of cultured Greenshell ${ }^{\mathrm{TM}}$ mussel spat, Perna canaliculus (Gmelin, 1791). Aquacult Int 19: 957-971

* Hickman RW (1976) Potential for the use of stranded seed mussels in mussel farming. Aquaculture 9:287-293

* Holthuis TD, Bergström P, Lindegarth M, Lindegarth S (2015) Monitoring recruitment patterns of mussels and fouling tunicates in mariculture. J Shellfish Res 34:1007-1018

* Hunt HL, Scheibling RE (1996) Physical and biological factors influencing mussel (Mytilus trossulus, $M$. edulis) settlement on a wave-exposed rocky shore. Mar Ecol Prog Ser 142:135-145

Hyndman RJ, Athanasopoulos G (2013) Forecasting: principles and practice, 2nd edn. OTexts, Melbourne. www. otexts.com/fpp2 (accessed December 2018)

Jeffs AG, Holland RC, Hooker SH, Hayden BJ (1999) Overview and bibliography of research on the greenshell mussel, Perna canaliculus, from New Zealand waters. J Shellfish Res 18:347-360

Jeffs AG, Delorme NJ, Stanley JA, Zamora LN, Sim-Smith C (2018) Composition of beachcast material containing green-lipped mussel (Perna canaliculus) seed harvested for aquaculture in New Zealand. Aquaculture 488:30-38

Kamermans P, Capelle JJ (2018) Provisioning of mussel seed and its efficient use in culture. In: Smaal AC, Ferreira JG, Grant J, Petersen JK, Strand $\varnothing$ (eds) Goods and services of marine bivalves. Springer International Publishing, Cham, p 27-49

Kamermans P, Galley T, Boudry P, Fuentes J and others (2013) Blue mussel hatchery technology in Europe. In: Allan G, Burnell G (eds) Advances in aquaculture hatchery technology. Woodhead Publishing, Oxford, p 339-373

Keough MJ, Downes BJ (1982) Recruitment of marine invertebrates: the role of active larval choices and early mortality. Oecologia 54:348-352

Kuhn M, Wing J, Weston S, Williams A and others (2018) caret: Classification and Regression Training. $\mathrm{R}$ package version 6.0-79. https://CRAN.R-project.org/package=caret

*LLauzon-Guay JS, Dionne M, Barbeau MA, Hamilton DJ (2005) Effects of seed size and density on growth, tissueto-shell ratio and survival of cultivated mussels (Mytilus edulis) in Prince Edward Island, Canada. Aquaculture 250:652-665

* Leathwick JR, Elith J, Francis MP, Hastie T, Taylor P (2006) Variation in demersal fish species richness in the oceans surrounding New Zealand: an analysis using boosted regression trees. Mar Ecol Prog Ser 321:267-281

Mackenzie L (2004) River inputs, re mineralisation and the spatial and temporal distribution of inorganic nutrients in Tasman Bay, New Zealand. NZ J Mar Freshw Res 38: 681-704

*MacKenzie L, Adamson J (2004) Water column stratification and the spatial and temporal distribution of phytoplankton biomass in Tasman Bay, New Zealand: implications 
for aquaculture. N Z J Mar Freshw Res 38:705-728

McGrath D, King PA, Gosling EM (1988) Evidence for the direct settlement of Mytilus edulis larvae on adult mussel beds. Mar Ecol Prog Ser 47:103-106

Meredyth-Young JL, Jenkins RJ (1978) Depth of settlement of two mussel species on suspended collectors in Marlborough Sounds, New Zealand (Note). NZ J Mar Freshw Res 12:83-86

Pérez Camacho A, Labarta U, Beiras R (1995) Growth of mussels (Mytilus edulis galloprovincialis) on cultivation rafts: influence of seed source, cultivation site and phytoplankton availability. Aquaculture 138:349-362

Peteiro LG, Filgueira R, Labarta U, Fernández-Reiriz MJ (2010) The role of fish predation on recruitment of Mytilus galloprovincialis on different artificial mussel collectors. Aquacult Eng 42:25-30

Pineda J, Porri F, Starczak V, Blythe J (2010) Causes of decoupling between larval supply and settlement and consequences for understanding recruitment and population connectivity. J Exp Mar Biol Ecol 392:9-21

Porri F, McQuaid CD, Radloff S (2006) Spatio-temporal variability of larval abundance and settlement of Perna perna: differential delivery of mussels. Mar Ecol Prog Ser 315:141-150

R Core Team (2018) R: a language and environment for statistical computing. R Foundation for Statistical Computing, Vienna

Rajagopal S, Venugopalan V, Nair K, Van der Velde G, Jenner $H$ (1998) Settlement and growth of the green mussel Perna viridis (L.) in coastal waters: influence of water velocity. Aquat Ecol 32:313-322

Seers BM, Shears NT (2015) New Zealand's climate data in R - an introduction to clifro. University of Auckland. https:// stattech.wordpress.fos.auckland.ac.nz/2015/03/25/201502-new-zealands-climate-data-in-r-an-introduction-toclifro/

Segal MR (1988) Regression trees for censored data. Biometrics 44:35-47

Sharples J, Greig MJN (1998) Tidal currents, mean flows,

Editorial responsibility: Gianluca Sará,

Palermo, Italy and upwelling on the north east shelf of New Zealand. NZ J Mar Freshw Res 32:215-231

Shirtcliffe TGL, Moore MI, Cole AG, Viner AB, Baldwin R, Chapman B (1990) Dynamics of the Cape Farewell upwelling plume, New Zealand. NZ J Mar Freshw Res 24:555-568

* South PM (2016) An experimental assessment of measures of mussel settlement: effects of temporal, procedural and spatial variations. J Exp Mar Biol Ecol 482:64-74

* South PM, Floerl O, Jeffs AG (2017) Differential effects of adult mussels on the retention and fine-scale distribution of juvenile seed mussels and biofouling organisms in longline aquaculture. Aquacult Environ Interact 9:239-256

Symonds JE, King N, Camara MD, Ragg NLC and others (2018) New Zealand aquaculture selective breeding: from theory to industry application for three flagship species. Proc World Congress on Genetics Applied to Livestock Production 11:1035

Tenzer R, Wiart A (2014) Evidence of the El Niño/La Niña climatic events in New Zealand over the last century. GSTF J Geol Sci 1:28-38

* Thorson G (1950) Reproductive and larval ecology of marine bottom invertebrates. Biol Rev Camb Philos Soc 25:1-45

* Toupoint N, Gilmore-Solomon L, Bourque F, Myrand B, Pernet F, Olivier F, Tremblay R (2012) Match/mismatch between the Mytilus edulis larval supply and seston quality: effect on recruitment. Ecology 93:1922-1934

* Trenberth KE (1984) Signal versus noise in the Southern Oscillation. Mon Weather Rev 112:326-332

* Troup AJ (1965) The Southern Oscillation. QJR Meteorol Soc 91:490-506

Zeldis JR, Howard-Williams C, Carter CM, Schiel DR (2008) ENSO and riverine control of nutrient loading, phytoplankton biomass and mussel aquaculture yield in Pelorus Sound, New Zealand. Mar Ecol Prog Ser 371: 131-142

Zuur AF, Ieno EN, Elphick CS (2010) A protocol for data exploration to avoid common statistical problems. Methods Ecol Evol 1:3-14

Submitted: June 28, 2019; Accepted: October 7, 2019 Proofs received from author(s): November 27, 2019 